\title{
Functional status of patients with large ventricular septal defect and pulmonary vascular disease 6 to I6 years after surgical closure of their defect in childhood
}

\author{
K. A. HALLIDIE-SMITH, R. S. E. WILSON, A. HART, AND E. ZEIDIFARD
}

From the Divisions of Cardiovascular and Respiratory Disease, Royal Postgraduate Medical School, Hammersmith Hospital, Du Cane Road, London

We have reviewed 27 patients now 6 to 16 years after closure of a ventricular septal defect at 3 to 12 years of age associated with pulmonary hypertension with a view to assessing their quality of life, respiratory function, and exercise performance.

All the patients led normal unrestricted lives. Their subjective lack of symptoms was, in general, confirmed by the results obtained from assessment of lung function tests and two-stage exercise testing in 19 volunteers. Abnormal ventilation in relation to work load was noted in 5 patients and a slightly low exercise cardiac output in 6.

Although the patients led normal lives and had a satisfactory response to exercise, measurement of pulmonary artery pressure showed striking pulmonary hypertension on effort.

Despite the satisfactory progress of these patients their more long-term future must be one of conjecture and their residual pulmonary hypertension, indicative of residual pulmonary obstruction, must lend weight to arguments for earlier closure of ventricular septal defect before 1 to 2 years of age when changes in the pulmonary vascular bed may be reversed after closure of the defect.

The first successful closures of ventricular septal defect were reported in 1955 (Lillehei et al., 1955; Kirklin et al., 1955) and so the early childhood survivors are now young adults. Without closure of their large ventricular septal defects many of these patients could have developed progressive pulmonary vascular obstruction leading to reversal of shunt and the Eisenmenger syndrome. The object of the present study is to evaluate the quality of life of long-term survivors of surgical closure of large ventricular septal defects with preoperative pulmonary hypertension and to assess their capacity for effort by formal exercise tests and resting and exercise haemodynamics. This study is essentially an extension of a previous clinical and haemodynamic study conducted 1 to 8 years after surgical correction (Hallidie-Smith et al., 1969).

\section{Patients}

We were able to follow up 27 patients, 25 of whom had been included in the previous study (HallidieReceived for publication 6 January 1977
Smith et al., 1969), now 6 to 16 years after operation. Before operation these 25 patients all had systolic pressures in the pulmonary artery at or within $15 \mathrm{mmHg}$ of that in the systemic arteries; all had a pulmonary arteriolar resistance of 8 units or above but all had clinical, radiological, and haemodynamic evidence of a pulmonary blood flow in excess of systemic. The other 2 patients who were studied (cases 14 and 15-Table 1), 6 and 8 years after operation, respectively, had systolic pulmonary arterial pressures at systemic level but low pulmonary resistances and pulmonary/systemic flow ratios of $4: 1$ and $5: 1$, respectively.

\section{Methods}

Twenty-one patients were interviewed and examined and a further 6 patients were contacted by letter. Each patient available for examination was weighed and measured and the values expressed as expected centiles of normal (Tanner, 1958). Each was questioned about his or her symptomatology, occupation, and leisure activities. 
Table 1 Clinical and haemodynamic data (19 patients)

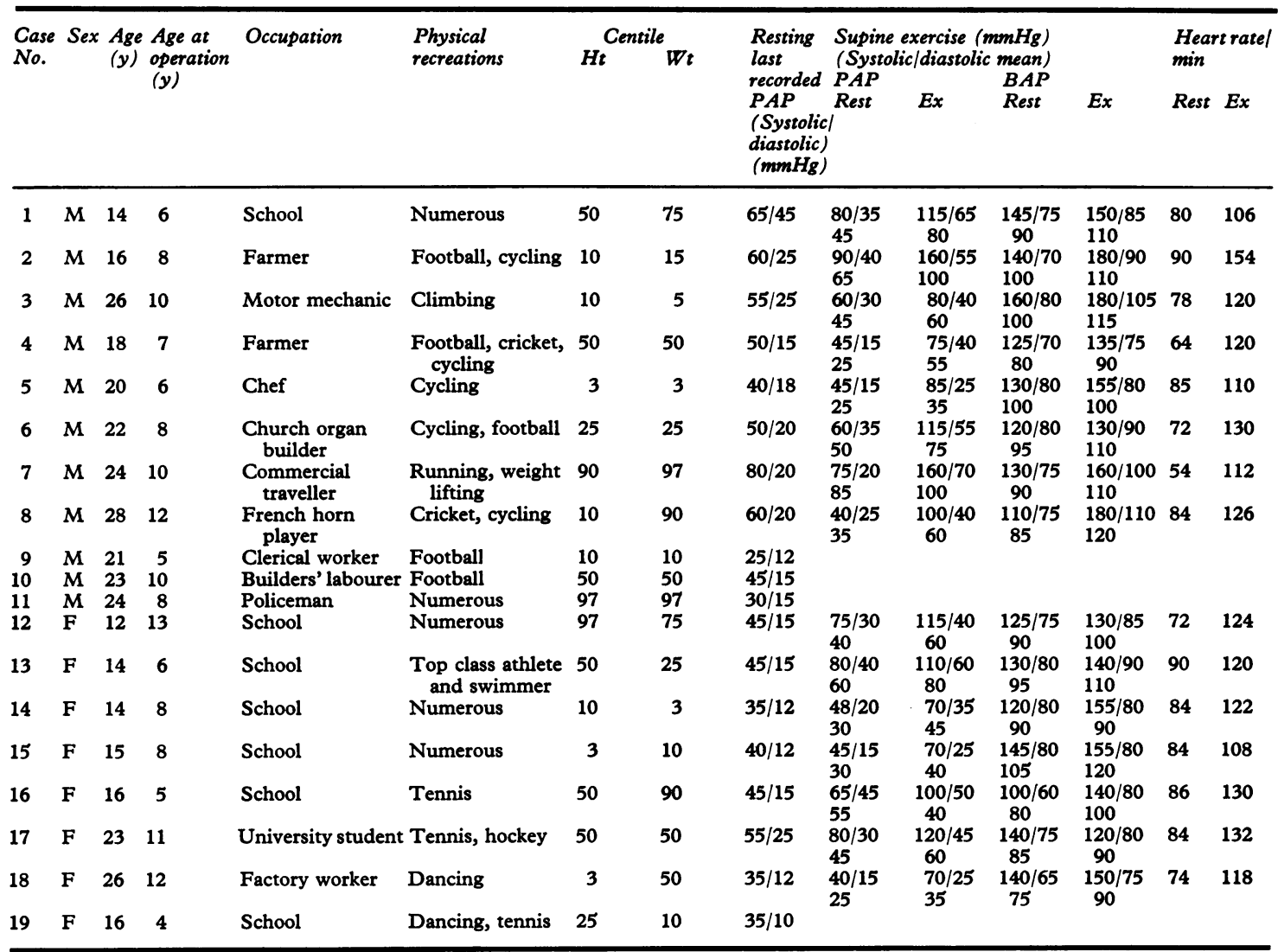

PAP, pulmonary arterial pressure; BAP, brachial arterial pressure.

LUNG FUNCTION TESTS (19 patients)

Forced expiratory volume in one second $\left(\mathrm{FEV}_{1}\right)$ and vital capacity (VC) were measured on a dry spirometer. Total lung capacity (TLC) was measured using constant volume plethysomography (Dubois et al., 1956). The carbon monoxide transfer factor (TLCO) was measured by the single breath method (Ogilvie et al., 1957). A bronchodilator (isoprenaline $100 \mu \mathrm{g}$ ) was given to assess reversibility of airways obstruction if present.

\section{EXERCISE TESTS}

Nineteen patients volunteered for two-stage exercise tests. These were performed on a constant work-rate bicycle ergometer (Elema-Schönander) at a room temperature of 19 to $22^{\circ} \mathrm{C}$. The stage $\mathrm{I}$, or increasing work load, test was carried out with the patients performing upright bicycle ergometry starting at zero load and increasing by $100 \mathrm{kpm} /$ minute. The test was stopped in 5 patients at 85 per cent of their predicted maximum heart rate (Astrand 1960) and continued until the patient could not continue in the other 14 . Inspired ventilation was measured on a dry gas meter (Parkinson Cassu C.D.). Mixed expired concentrations of carbon dioxide $\left(\mathrm{CO}_{2}\right)$ and oxygen $\left(\mathrm{O}_{2}\right)$ were estimated (accuracy $\pm 0.05 \%$ ) on a URAS capnograph and Servomex OA 137 oxygen analyser. The analysers were calibrated with a range of previously determined $\mathrm{CO}_{2} / \mathrm{O}_{2}$ gas mixtures. These values were continuously monitored on a Mingograph 81 recorder and total ventilation (VE), oxygen intake $\left(\mathrm{VO}_{2}\right)$, and carbon dioxide output $\left(\mathrm{VCO}_{2}\right)$ were calculated. Throughout the test an electrocardiogram was simultaneously monitored on the recorder and oscilloscope screen from which the heart rate was measured. There was a period of $\mathbf{3 0}$ to $\mathbf{4 0}$ minutes' rest before the second stage.

The stage II, or steady state, exercise test was carried out in 18 patients at two-thirds of the pre- 
viously determined maximum working capacity. Throughout exercise ventilation, electrocardiogram and expired $\mathrm{O}_{2}$ and $\mathrm{CO}_{2}$ were displayed on the Mingograph recorder as before. When steady state was reached-usually at about 4 minutes-the cardiac output was estimated using the indirect $\mathrm{CO}_{2}$ Fick equation. Arterialised ear lobe blood was taken at rest and on exercise (after 4 to 5 minutes) for the determination of $\mathrm{PaCO}_{2}, \mathrm{PaO}_{2}$, and lactate (Hohorst, 1957). In 6 patients the blood samples were inadequate and corrected end-tidal $\mathrm{CO}_{2}$ (Jones et al., 1967) was used as an estimation of arterial $\mathrm{CO}_{2}$. Mixed venous $\mathrm{CO}_{2}\left(\mathrm{PvCO}_{2}\right)$ was then determined by the plateau $\mathrm{CO}_{2}$ rebreathing technique without correction for the downstream effect (Jones et al., 1967). If the plateau was unsatisfactory an extrapolate of $\mathrm{PvCO}_{2}$ was derived (Denison et al., 1969).

\section{CARDIAC CATHETERISATION}

Fifteen patients agreed to have cardiac catheterisation performed with the object of measuring the pulmonary artery pressure at rest and during exercise in the supine position. The patients had already experienced at least one previous postoperative catheterisation so it was already known that $\mathbf{4}$ had a small residual ventricular septal defect. In 3 patients there was a significant step up in oxygen saturation and the ratio of pulmonary to systemic flow was 1.5:1 or less (cases 5,6 and 8 ). The remaining defect could be detected only by green dye dilution technique (case 13).

Catheters were introduced percutaneously into a median cubital vein and brachial artery. The venous catheter was advanced to the pulmonary artery so that resting pulmonary arterial and brachial arterial pressures could be recorded and blood samples for oxygen saturation obtained. The zero level for the pressure measurements was the mid chest. The patients were then exercised supine for 3 minutes using alternate leg raising, the ankles being placed in wide slings with counterbalanced weights run over pulleys. The phasic pulmonary arterial and brachial arterial pressures were recorded throughout the exercise and the mean pressures each minute. Oxygen saturations were estimated at rest and immediately before the end of the exercise.

In 8 patients the arterial catheter was advanced into the left ventricle and after a 10-minute rest period the exercise test was repeated and left ventricular end-diastolic pressure recorded and left ventricular stroke work calculated at rest and after 3 minutes of exercise. Cardiac output was measured at rest and exercise by the indocyanine green dye dilution technique.

The day-to-day occupation of French horn playing of one patient (case 8) was simulated by blowing in the supine position with simultaneous recording of pulmonary arterial and brachial arterial pressures.

Six patients volunteered to exercise in the upright position on the bicycle ergometer with pulmonary and brachial arterial lines in position. They performed an increasing work load test, starting at zero load and increasing by $100 \mathrm{kpm}$ each minute until their known maximum work load was reached. Measurements of pulmonary and brachial arterial pressures were made at rest, at minute intervals, and at maximum work load with the measurement made from the xiphisternum.

\section{Results}

Twenty-one patients were interviewed and examined and a further 6 patients were contacted by letter. All except 1 patient said that they were symptom free with normal exercise tolerance. The exception (case 16) was overweight but said she lacked energy and could not sustain a prolonged game of tennis. There were 14 male and 13 female patients. Ten were still attending school and one was a university student. Of the 15 who had left school, one (mentally retarded) is at a training centre, one young woman had married and had one healthy normal baby, and the others were all in full-time employment, 6 involving heavy manual work. Four of the male patients had married and had children. All the patients remarked that they felt completely unrestricted both at work and in their leisure time and the young men seemed to participate more than the average in active sports of many varieties. Before operation all the patients were under weight (many less than 3rd centile), and short in stature (many less than 10th centile). All improved after closure of the ventricular septal defect and 2 young men are above 90th centile for height (cases 7 and 11). The individual clinical and haemodynamic findings in 19 patients who volunteered for tests of lung function are detailed in Table 1 .

\section{LUNG FUNCTION TESTS (Table 2)}

Lung function tests were normal for the group as a whole but 2 showed mild restrictive ventilatory defects (cases 2 and 12). The former patient also had a low total lung capacity, residual volume, and transfer factor. The latter had a normal transfer factor but total lung capacity was not measured. Two others (cases 10 and 16) had mild airways obstruction not reversed by bronchodilator and case 16 also had a reduced transfer factor. Neither gave a history of asthma and both were nonsmokers. 
Table 2 Lung function results

\begin{tabular}{|c|c|c|c|c|c|}
\hline Case No. & $F E V_{1}(s)$ & $V C$ & $\frac{F E V_{1} s}{V C}($ per cent $)$ & $T L C$ & $T L C O$ \\
\hline 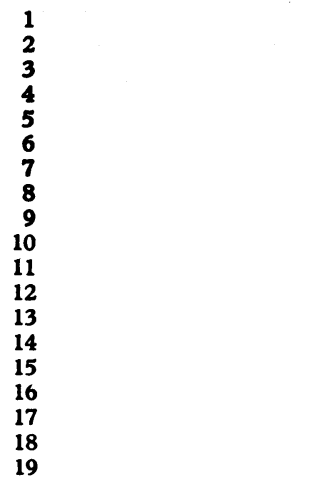 & $\begin{array}{l}2.40 \\
2.45 \\
3.85 \\
3.80 \\
2 \cdot 80 \\
4.20 \\
4.50 \\
3.10 \\
3.70 \\
3.10 \\
4.60 \\
1.85 \\
2 \cdot 10 \\
2.60 \\
2.05 \\
3.10 \\
2.00 \\
2.30\end{array}$ & $\begin{array}{l}3 \cdot 00 \\
2 \cdot 80 \\
4 \cdot 05 \\
4 \cdot 90 \\
3.50 \\
5 \cdot 35 \\
5 \cdot 40 \\
3 \cdot 70 \\
4 \cdot 20 \\
4 \cdot 50 \\
5 \cdot 20 \\
2 \cdot 25 \\
2 \cdot 50 \\
-2 \cdot 80 \\
3.05 \\
3.90 \\
2 \cdot 20 \\
2 \cdot 40\end{array}$ & $\begin{array}{l}80 \\
88 \\
95 \\
78 \\
80 \\
79 \\
83 \\
85 \\
88 \\
69 \\
88 \\
82 \\
84 \\
93 \\
67 \\
79 \\
91 \\
96\end{array}$ & $\begin{array}{l}4 \cdot 25 \\
3 \cdot 60 \\
6 \cdot 85 \\
5 \cdot 60 \\
6 \cdot 10 \\
- \\
5 \cdot 30 \\
6 \cdot 30 \\
6 \cdot 10 \\
6 \cdot 81 \\
3 \cdot 30 \\
\overline{4.10} \\
3.90 \\
5.00 \\
3.90 \\
3 \cdot 40\end{array}$ & $\begin{array}{l}21.8 \\
21.7 \\
\overline{32.5} \\
35.6 \\
35.9 \\
\overline{26} \cdot 9 \\
28 \cdot 7 \\
33 \cdot 1 \\
35 \cdot 2 \\
17 \cdot 2 \\
18.2 \\
14.7 \\
14.3 \\
19.2 \\
20.6 \\
18.0 \\
20.1\end{array}$ \\
\hline $\begin{array}{l}\text { Mean } \pm \text { SD } \\
\% \text { Predicted mean } \pm \text { SD } \\
\text { Norman range } \% \text { Predicted }\end{array}$ & $\begin{array}{l}3 \cdot 00 \pm 0 \cdot 42 \\
85 \cdot 4 \pm 14 \\
80-120\end{array}$ & $\begin{array}{l}3.65 \pm 0.47 \\
90 \cdot 2 \pm 13 \\
80-120\end{array}$ & $\begin{array}{l}84 \pm 7 \\
>75\end{array}$ & $\begin{array}{l}4.93 \pm 0.74 \\
93 \cdot 8 \pm 15 \\
80-120\end{array}$ & $\begin{array}{l}24 \cdot 4 \pm 3 \cdot 2 \\
86 \cdot 9 \pm 1 \cdot 3 \\
>75\end{array}$ \\
\hline
\end{tabular}

FEV $_{18}$ forced expiratory volume in 1 second-litres/second; VC, vital capacity-litres; TLC, total lung capacity-litres; TLCO, carbon monoxide transfer factor $-\mathrm{ml} / \mathrm{mmHg}$ per $\mathrm{min}$.

*Normal data (Cotes, 1968).

INCREASING WORK LOAD TESTS (Table 3)

The increasing work load tests carried out on 11 male and 8 female patients showed a low maximum work load for the group as a whole. However, 5 patients were stopped when they reached 85 per cent of predicted maximum heart rate for normal subjects (Astrand, 1960). One male patient (case 2) stopped at 60 per cent of predicted maximum work load. The female patients were less enthusiastic than the males and averaged only 63 per cent of predicted maximum work load. Five stopped because of aching legs at a time when both heart rate and ventilation were quite appropriate for the work load reached. Two female patients (cases 13 and 16) had grossly abnormal ventilation for the work load reached and stopped because of breathlessness; case 16 was subsequently unable to complete the steady state exercise test. The results of these 2 female patients and 1 male patient (case 2) are the only definitely abnormal exercise responses.

\section{STEADY STATE EXERCISE TEST (Table 4)}

The cardiac and metabolic response to steady state exercise test was normal for the group. At rest blood gases and lactate were normal in all except case 13 who had a low $\mathrm{PaCO}_{2}$. The cardiac output was calculated to be normal at rest in all patients but since the indirect Fick method can be variable at rest, these data are omitted.

The cardiac output during submaximal steady state exercise (Fig. 1) was within normal limits in 12 patients and below normal in 6 (cases 2, 5, 7, 9,13 , and 15). Three patients (cases 3, 8, and 13) had a high venous admixture ratio. Arterial oxygen tension was low in 5 (cases 3, 5, 7, 8, and 13) and blood lactate was marginally high in case 5 .

Table 3 Increasing work load test

\begin{tabular}{|c|c|c|c|c|c|}
\hline $\begin{array}{l}\text { Case } \\
\text { No. }\end{array}$ & Sex & $\begin{array}{l}\text { Maximum } \\
\text { work load } \\
(W \text { max }) \\
\text { kpm/min }\end{array}$ & $\begin{array}{l}W \max \\
\text { observed } \\
\text { expected } \\
\%\end{array}$ & $\begin{array}{l}\text { Heart rate } \\
\text { at } W \text { max } \\
\text { beats } / \text { min }\end{array}$ & $\begin{array}{l}\text { Ventilation } \\
\text { at } W \text { max } \\
l / \min \end{array}$ \\
\hline $\begin{array}{l}1 \\
2 \\
3 \\
4^{\star} \\
5 \\
6^{\star} \\
7 \\
8 \\
9^{\star} \\
10^{\star} \\
11^{\star} \\
12 \\
13 \\
14 \\
15 \\
16 \\
17 \\
18 \\
19\end{array}$ & 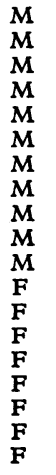 & $\begin{array}{r}700 \\
600 \\
800 \\
1000 \\
900 \\
800 \\
1100 \\
800 \\
900 \\
800 \\
1100 \\
500 \\
500 \\
400 \\
700 \\
400 \\
600 \\
400 \\
500\end{array}$ & $\begin{array}{r}70 \\
60 \\
73 \\
83 \\
86 \\
67 \\
85 \\
73 \\
82 \\
67 \\
85 \\
63 \\
63 \\
57 \\
100 \\
44 \\
67 \\
57 \\
63\end{array}$ & $\begin{array}{l}170 \\
182 \\
170 \\
164 \\
153 \\
175 \\
182 \\
173 \\
186 \\
169 \\
164 \\
166 \\
179 \\
175 \\
179 \\
170 \\
169 \\
108 \\
155\end{array}$ & \begin{tabular}{r}
40.6 \\
33.3 \\
\multicolumn{1}{c}{-} \\
54.2 \\
59.5 \\
56.8 \\
106.0 \\
67.9 \\
58.7 \\
56.0 \\
63.7 \\
32.8 \\
50.2 \\
22.0 \\
53.2 \\
52.4 \\
59.0 \\
19.8 \\
32.0
\end{tabular} \\
\hline$\underset{\text { SD }}{\text { Mean }}$ & & $\begin{array}{r}711 \\
23\end{array}$ & $\begin{array}{l}71 \\
13\end{array}$ & $\begin{array}{r}168 \\
17\end{array}$ & $\begin{array}{l}51 \\
20\end{array}$ \\
\hline
\end{tabular}

^Exercise stopped at 85 per cent predicted maximum heart rate (Astrand, 1960). Predicted values from Godfrey et al. (1971b). 


\section{CARDIAC CATHETERISATION}

The last known resting pulmonary arterial pressures before the present study are shown in Table 1, and the resting and exercise pulmonary and brachial arterial phasic and mean pressures and heart rates recorded during this study are also shown. Serial resting pulmonary arterial pressures of the 15 patients currently studied are shown in Fig. 2 and supine resting and exercise pulmonary artery pressure (after 3 minutes of alternate leg raising) are shown in Fig. 3 (15 patients).

Table 4 Results of stage 2 : steady state exercise test

\begin{tabular}{|c|c|c|c|c|c|c|c|c|}
\hline Case No. & $\begin{array}{l}\text { Oxygen intake } \\
\text { (l/min) }\end{array}$ & $\begin{array}{l}\text { Arterial } \mathrm{PO}_{2} \\
(\mathrm{~mm} \mathrm{mg})\end{array}$ & $\begin{array}{l}\text { Arterial Paco, } \\
(\mathrm{mmHg})\end{array}$ & $\begin{array}{l}\text { Lactate } \\
(m E q / l)\end{array}$ & $\begin{array}{l}\text { Cardiac output } \\
\text { (l/min) }\end{array}$ & $\begin{array}{l}\text { Venous admixture } \\
(Q s / Q t)(\%)\end{array}$ & $\begin{array}{l}\text { Heart rate } \\
\text { (beats/min) }\end{array}$ & $\begin{array}{l}\text { Stroke volume } \\
\text { (ml/min) }\end{array}$ \\
\hline $\begin{array}{r}1 \\
2 \\
3 \\
4 \\
5 \\
6 \\
7 \\
8 \\
9 \\
10 \\
11 \\
12 \\
13 \\
14 \\
15 \\
17 \\
18 \\
19\end{array}$ & $\begin{array}{l}1.08 \\
1.26 \\
1.44 \\
1.57 \\
1.69 \\
1.46 \\
2.05 \\
1.41 \\
1.48 \\
1.37 \\
1.60 \\
0.92 \\
1.15 \\
0.71 \\
1.06 \\
1.31 \\
0.77 \\
0.99\end{array}$ & $\begin{array}{r}92 \\
86 \\
68 \\
88 \\
75 \\
87 \\
75 \\
72 \\
100 \\
95 \\
103 \\
105 \\
56 \\
- \\
102 \\
99 \\
103 \\
98\end{array}$ & $\begin{array}{l}35 \\
37 \\
32 \\
40 \\
29 \\
34 \\
28 \\
31 \\
36 \\
41 \\
39 \\
39 \\
30 \\
42 \\
32 \\
27 \\
37 \\
35\end{array}$ & $\begin{array}{l}2 \cdot 6 \\
2 \cdot 7 \\
3 \cdot 2 \\
1 \cdot 1 \\
6 \cdot 0 \\
2 \cdot 7 \\
3 \cdot 8 \\
2 \cdot 0 \\
1 \cdot 5 \\
1.9 \\
5 \cdot 1 \\
4 \cdot 3 \\
2 \cdot 7 \\
1.5 \\
2.0\end{array}$ & $\begin{array}{r}8.0 \\
7.7 \\
10.5 \\
10.7 \\
8.8 \\
11.0 \\
12.3 \\
11.8 \\
8.7 \\
10.3 \\
13.5 \\
7 \cdot 1 \\
6.7 \\
5.8 \\
6.9 \\
9.6 \\
7.0 \\
7.4\end{array}$ & $\begin{array}{c}2.4 \\
2.7 \\
7.2 \\
2.4 \\
4.1 \\
3.4 \\
5.0 \\
6.8 \\
0.5 \\
1.9 \\
0.3 \\
11.3 \\
1.0 \\
2.0 \\
0.2 \\
1.4\end{array}$ & $\begin{array}{r}143 \\
152 \\
180 \\
123 \\
152 \\
142 \\
170 \\
141 \\
155 \\
149 \\
129 \\
135 \\
165 \\
169 \\
138 \\
139 \\
91 \\
134\end{array}$ & $\begin{array}{r}53 \\
51 \\
58 \\
87 \\
57 \\
78 \\
72 \\
84 \\
56 \\
69 \\
104 \\
53 \\
41 \\
34 \\
50 \\
69 \\
80 \\
55\end{array}$ \\
\hline $\begin{array}{l}\text { Summarised } d \\
\text { Mean } \pm S D\end{array}$ & $\begin{array}{r}1.30 \\
\pm 0.34\end{array}$ & $\begin{array}{r}88 \\
\pm 15\end{array}$ & $\begin{array}{r}35 \\
5\end{array}$ & $\begin{array}{r}2 \cdot 8 \\
\pm 1 \cdot 4\end{array}$ & $\begin{array}{r}9 \cdot 1 \\
\pm 2 \cdot 2\end{array}$ & $\begin{array}{r}3 \cdot 4 \\
\pm 3 \cdot 1\end{array}$ & $\begin{array}{r}144 \\
\pm 23\end{array}$ & $\begin{array}{r}64 \\
\pm 12\end{array}$ \\
\hline $\begin{array}{l}\text { Per cent of prec } \\
\text { Mean } \pm S D\end{array}$ & licted normal va & alue & 一 & 一 & $\begin{array}{r}80 \\
\pm 11\end{array}$ & 一 & $\begin{array}{r}95 \\
\pm 16\end{array}$ & $\begin{array}{r}85 \\
\pm 18\end{array}$ \\
\hline Normal range & - & $>85$ & 一 & $2 \cdot 0-5 \cdot 5$ & $80-120$ & $1 \cdot 0-4 \cdot 4$ & $80-120$ & $80-120$ \\
\hline
\end{tabular}

Normal values taken from Spiro (1975). Q8/Qt, volume of right to left shunts as percentage of systemic cardiac output.

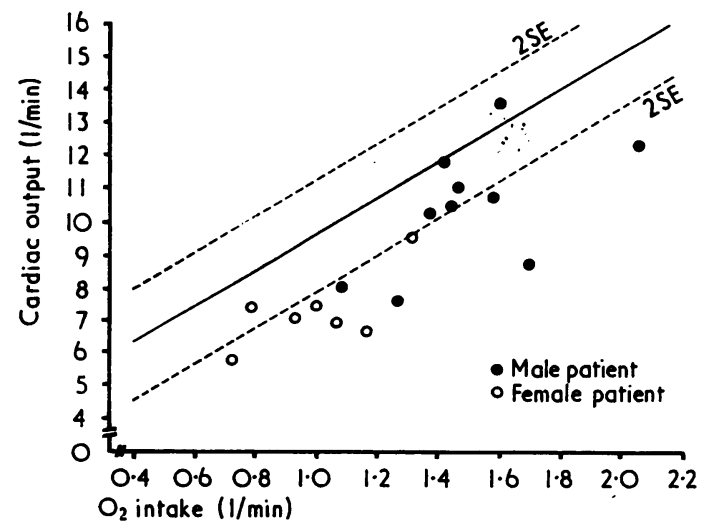

Fig. 1 Cardiac output during steady state exercise related to oxygen consumption. Normal value lines from Godfrey et al. (1971a). 
Resting pulmonary 14aerial pressure (Fig. 4)

Of the 15 patients under discussion who volunteered for supine exercise recording of their pulmonary arterial pressure none could be considered to have a normal pulmonary arterial pressure (systolic pressure of $30 \mathrm{mmHg}$ or less at rest). Values of $70 \mathrm{mmHg}$ or more (systolic) were recorded in 8 patients. The serial recordings of pulmonary arterial pressure suggested that pulmonary hypertension might be progressive in 4 patients and in no patient could it be regarded as becoming less severe.

\section{Supine exercise}

The supine measurements of pulmonary and brachial arterial pressures and heart rate at rest and on effort are set out in Table 1, and the pulmonary arterial systolic pressures are shown in Fig. 3. It

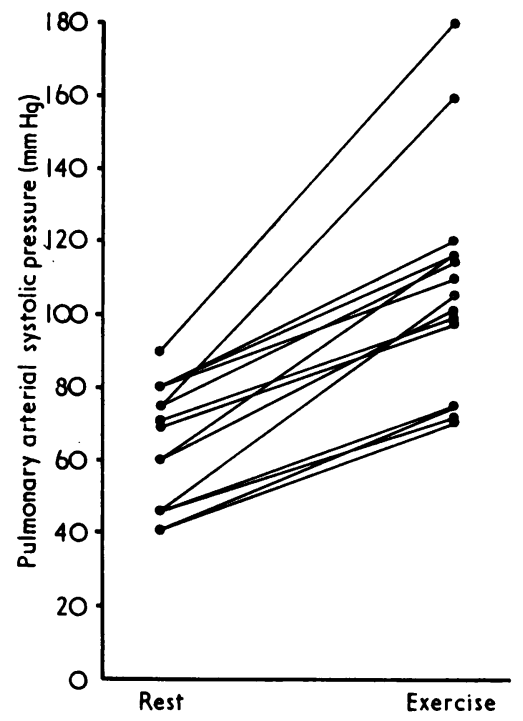

Fig. 3 Pulmonary artery systolic pressure at rest and on completion of 3 minutes of supine leg raising (15 patients). should be emphasised that the exercise called for only brief effort; this was not standardised and some patients put in much greater physical work than others who had to be much encouraged. In 5 patients the exercise pulmonary arterial pressure rose to close approximation with systemic (cases 2 , $6,7,12,13$, and 17) and in all except 3 patients (cases 3,14 , and 15) the rise of systolic pulmonary arterial pressure was $30 \mathrm{mmHg}$ or more.

\section{Upright exercise (Table 5 and Fig. 4)}

The upright maximum work load test with pulmonary artery and brachial artery lines in situ was completed by all 6 volunteers whose maximum work load was already known. In 3 patients the pulmonary arterial systolic pressure was within $30 \mathrm{mmHg}$ of the systemic arterial systolic pressure at maximum work load (cases 1,6 , and 12).

\section{Left ventricular function (Fig. 5)}

Left ventricular stroke work was calculated in the 8 patients in whom left ventricular pressures were recorded at rest and after 3 minutes leg exercise.

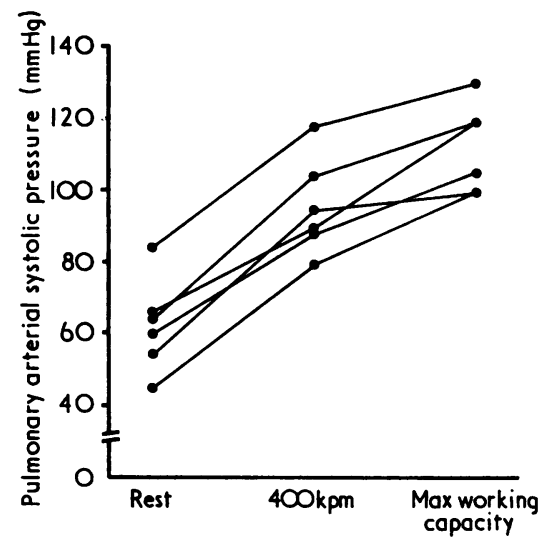

Fig. 4 Increasing work load test pulmonary artery systolic pressure (6 patients).

Table 5 Bicycle progressive work load test in 6 patients

\begin{tabular}{|c|c|c|c|c|c|c|c|c|c|}
\hline Case No. & $\begin{array}{l}\text { Rest } \\
P A \\
(\mathrm{~mm} H g)\end{array}$ & $\begin{array}{l}B A \\
(m m H g)\end{array}$ & $H R / \min$ & $\begin{array}{l}A t 400 \mathrm{kpm} \\
P A \\
(\mathrm{mmHg})\end{array}$ & $\begin{array}{l}B A \\
(m m H g)\end{array}$ & $H R / \min$ & $\begin{array}{l}\text { Max work } \\
P A \\
(m m H g)\end{array}$ & $\begin{array}{l}a d \\
(m \boldsymbol{A} A \\
(m g)\end{array}$ & $H R / \min$ \\
\hline $\begin{array}{r}1 \\
3 \\
5 \\
6 \\
8 \\
12\end{array}$ & $\begin{array}{l}84 / 45 \\
55 / 32 \\
45 / 15 \\
66 / 35 \\
60 / 25 \\
65 / 30\end{array}$ & $\begin{array}{l}158 / 100 \\
102 / 60 \\
130 / 80 \\
105 / 60 \\
120 / 80 \\
134 / 84\end{array}$ & $\begin{array}{l}84 \\
90 \\
92 \\
70 \\
88 \\
98\end{array}$ & $\begin{array}{r}118 / 60 \\
95 / 55 \\
80 / 30 \\
90 / 45 \\
88 / 40 \\
105 / 70\end{array}$ & $\begin{array}{l}148 / 100 \\
100 / 80 \\
160 / 90 \\
120 / 80 \\
130 / 80 \\
140 / 90\end{array}$ & $\begin{array}{l}130 \\
135 \\
142 \\
115 \\
122 \\
160\end{array}$ & $\begin{array}{l}130 / 75 \\
100 / 60 \\
100 / 40 \\
120 / 80 \\
105 / 45 \\
120 / 80\end{array}$ & $\begin{array}{l}150 / 110 \\
150 / 85 \\
160 / 105 \\
130 / 85 \\
155 / 100 \\
145 / 90\end{array}$ & $\begin{array}{l}190 \\
180 \\
196 \\
194 \\
196 \\
180\end{array}$ \\
\hline
\end{tabular}

PA, pulmonary arterial pressure; BA, brachial arterial pressure; HR, heart rate per minute. 


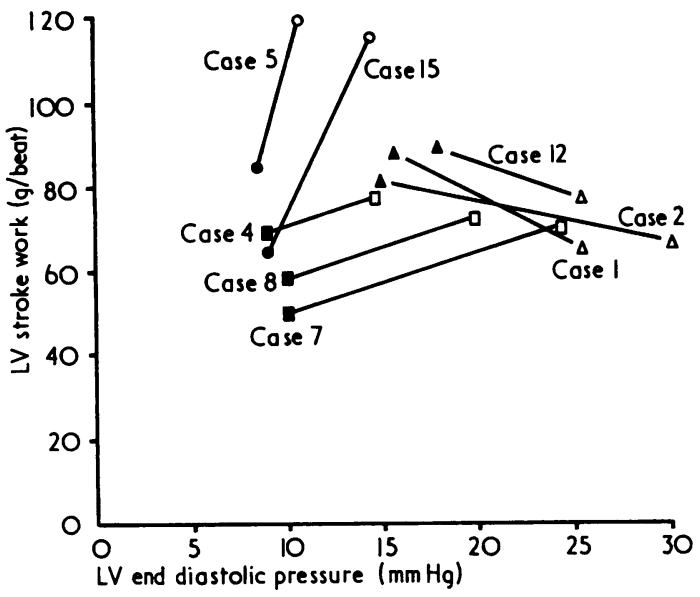

Fig. 5 Left ventricular function at rest and during supine exercise in patients with repaired ventricular septal defect. Solid symbols: at rest; open symbols : during exercise.

Left ventricular end-diastolic pressure was normal at rest in 5 of them and slightly raised in 3 (cases 1,2 , and 12), but on effort it rose to 20 to 30 $\mathrm{mmHg}$ in 5 of the 8 patients. Those patients with mild resting pulmonary hypertension were able to increase their left ventricular stroke work while maintaining a normal left ventricular filling pressure while those with more severe pulmonary hypertension had an abnormal rise in left ventricular filling pressure with either a small increase or fall in left ventricular stroke work, suggesting impaired left ventricular function.

\section{Haemodynamics in simulated work}

We were anxious to record haemodynamic events during the day-to-day life of our patients. One of them (case 8), a professional French horn player, volunteered to simulate blowing his instrument while on the catheter table with pulmonary arterial and brachial arterial pressures recorded simultaneously. We recorded a pulmonary arterial pressure varying between $70 / 20$ and $100 / 75 \mathrm{mmHg}$ during this manoeuvre with simultaneous corresponding brachial arterial pressure of $120 / 80$ and $160 / 105 \mathrm{mmHg}$, respectively.

\section{Discussion}

There are few reports of the effects of a ventricular septal defect or pulmonary hypertension on lung function. Kimball and McIlroy (1966) described restrictive ventilation defects with high residual volumes in 3 patients with ventricular septal defects. McIlroy and Apthorp (1958) considered the effects of isolated pulmonary hypertension on lung function to be negligible, though a low carbon monoxide transfer factor possibly secondary to abnormal pulmonary vasculature has been occasionally described (Turino et al., 1959).

In the present study 2 patients had restrictive ventilatory defects, 1 with a low transfer factor, possibly relating to pulmonary hypertension. Two other patients had mild irreversible airways obstruction which may have been the result of their previous recurrent chest infections in infancy. In the 4 patients with abnormalities of lung function the ventilation reached during exercise was below the calculated voluntary minute ventilation (as assessed by $\left.F_{E V} \times 35\right)$, suggesting that impaired lung function played no part in reducing maximum working capacity.

The majority of our patients have been shown to exercise normally but some have a low cardiac output on exercise which supports the findings of Maron et al. (1973) and Lueker et al. (1969), who exercised patients after closure of a ventricular septal defect in the upright and supine positions, respectively. Johnson (1962) and Jonsson and Lee (1968) showed that patients who had had a pulmonary valvotomy for pulmonary valve stenosis may also have a low cardiac output on exercise. The latter suggested that the peripheral circulation might be adapted to extract and use oxygen to a greater degree than normally and that persistence of this adaptive mechanism after operation might result in a lesser rise in cardiac output than is normally expected on effort. However, impairment of left or right ventricular function, or both, cannot be excluded and it could also be suggested that abnormal pulmonary vascular activity might limit cardiac output (Lueker et al., 1969). However, in our series the finding of a low cardiac output on effort was not confined to those with severe pulmonary hypertension. Impaired left ventricular function has also been suspected in patients after closure of ventricular septal defect by finding raised left atrial pressures on exercise (HallidieSmith et al., 1969; Maron et al., 1973). More recently, Graham (1974) noted a decreased left ventricular ejection fraction in a similar group of patients. A decrease in left ventricular end-diastolic volume was also noted before operation, raising the question as to whether left ventricular function is ever normal in a patient with a large ventricular septal defect. Graham suggests that the decrease in ejection fraction may become apparent after operation because of the decreased after-load after closure of the ventricular septal defect. Our own findings are limited and relate only to postoperative studies but 
suggest that there may be impairment of left ventricular function on effort, most obvious in those patients with the more severe residual pulmonary hypertension.

In support of our patients' lack of symptoms we have the objective evidence of their varied employments, their sporting activities, sometimes keenly competitive, of their normal respiratory function tests and the normal exercise performance of the majority. These findings contrast with the conspicuously abnormal measurements of pulmonary arterial pressure recorded in the majority of patients at rest and in all patients on effort including the 2 patients in whom pulmonary vascular disease was not detected before operation. Some of our patients must be subjected to severe pulmonary hypertension during the course of their day-to-day activities as shown by our French horn player (case 8) whose increase in pulmonary arterial pressure could not be explained on the basis of a raised intrathoracic pressure or normal Valsalva response (Lee et al., 1954). Our overall findings of pulmonary hypertension suggest that preoperative changes in the pulmonary vascular bed have failed to resolve to a greater or lesser extent. Thus, even those patients with a normal or nearly normal resting pulmonary arterial pressure may show a pronounced increase in pulmonary arterial pressure on effort because of limitation of the pulmonary vascular bed, perhaps related to lack of elasticity of small pulmonary vessels or fixed pulmonary vasoconstriction.

Serial records of pulmonary arterial pressure in our patients now 6 to 16 years after closure of their ventricular septal defects have not suggested any remission of pulmonary hypertension though in 10 of the 15 patients there is no evidence of progression. However, in 5 patients there is some increase in pulmonary arterial pressure and Weidman and DuShane (1974) noted a progressive increase in pulmonary vascular resistance in 4 of 12 comparable patients.

It was recognised that all except 2 of our patients had developed pulmonary vascular disease before closure of their defect; but the 2 in whom it was not recognised (cases 14 and 15), nevertheless, had been shown to have exercise pulmonary hypertension, suggesting that they already had some reduction of their pulmonary vascular bed by obstructive disease before operation. Thus, it seems that pulmonary vascular disease may already be established by early childhood in any patient with a large ventricular septal defect. This may not completely regress after operation and indeed may progress. Vogel et al. (1974) have shown the importance of the vasoconstrictive element and it seems likely that those individuals whose pul- monary blood flow was appreciably increased by vasodilators when investigated before operation may have the best chance of good long-term results. However, the most important long-term prognostic factor may be the age at which the ventricular septal defect is closed. Our patients were all over 2 years of age at the time of closure of their defect but recent advances in surgical and cardiopulmonary bypass techniques have made closure of ventricular septal defects in infants over 6 months of age a safe procedure (Weidman and DuShane, 1974). The Eisenmenger syndrome is rare below the age of 2 years and it has been shown that pulmonary arterial intimal changes are rare in the first year of life (Hislop et al., 1975), and in infancy failure of the pulmonary vascular resistance to fall may not necessarily imply a poor long-term prognosis (Wagenvoort and Wagenvoort, 1974). Thus it seems advisable to recommend closure of a large ventricular septal defect with pulmonary hypertension well before the age of 2 years to ensure a satisfactory long-term result and the results of the present series should act as impetus to early surgical correction. The life expectancy and prognosis of our patients must remain in doubt, perhaps on the continued ability of the right ventricle to sustain the severe pulmonary hypertension which has challenged it from birth, on adequate left ventricular function and on factors which determine the progressive nature of pulmonary vascular obliterative changes. Thus far, however, the quality of life for these young men and women has been very good and certainly superior to that expected of comparable patients with ventricular septal defects and pulmonary vascular disease treated medically.

We thank Dr. B. Sharma, Dr. P. Lobstein, and Dr. J. Maldonado for their help in the haemodynamic studies, and Professor J. F. Goodwin and Dr. R. H. T. Edwards for their advice and criticism.

\section{References}

Astrand, I. (1960). Aerobic work capacity in men and women with special reference to age. Acta Physiologice Scandinavica, 49, Suppl. 169.

Cotes, J. E. (1968). Lung Function, 2nd ed. Blackwell, Oxford. Denison, D., Edwards, R. H. T., Jones, G., and Pope, H. (1969). Direct and rebreathing estimates of the $\mathrm{O}_{2}$ and $\mathrm{CO}_{2}$ pressures in mixed venous blood. Respiration Physiology, 7, 326-334.

Dubois, A. B., Botelho, S. Y., Bedell, G. N., Marshall, R., and Comroe, J. H., Jr. (1956). A rapid plethysmographic method for measuring thoracic gas volume: a comparison with a nitrogen washout method for measuring functional residual capacity in normal subjects. Fournal of Clinical Investigation, 35, 322-326. 
Godfrey, S., Davies, C. T. M., Wozniak, E., and Barnes, C. A. (1971a). Cardio-respiratory response to exercise in normal children. Clinical Science, 40, 419-431.

Godfrey, S., Wozniak, E. R., Courtenay Evans, R. J., and Samuels, C. S. (1971b). Ear lobe samples for blood gas analysis at rest and during exercise. British fournal of Diseases of the Chest, 65, 58-64.

Graham, T. P., Jr. (1974). Ventricular performance in patients following corrective surgery for congenital heart disease. Advances in Cardiology, 11, 81-106.

Hallidie-Smith, K. A., Hollman, A., Cleland, W. P., Bentall, H. H., and Goodwin, J. F. (1969). Effects of surgical closure of ventricular septal defects upon pulmonary vascular disease. British Heart fournal, 31, 246-260.

Hislop, A., Haworth, S. G., Shinebourne, E. A., and Reid, L. (1975). Quantitative structural analysis of pulmonary vessels in isolated ventricular septal defect in infancy. British Heart fournal, 37, 1014-1021.

Hohorst, H. J. (1957). Enzymatische Bestimming Von L (+) Milchsäure. Biochemische Zeitschrift, 328, 509-521.

Johnson, A. M. (1962). Impaired exercise response and other residua of pulmonary stenosis after valvotomy. British Heart fournal, 24, 375-388.

Jones, N. L., Campbell, E. J. M., McHardy, G. J. A., Higgs, B. E., and Clode, M. (1967). The estimation of carbon dioxide pressure of mixed venous blood during exercise. Clinical Science, 32, 311-327.

Jonsson, B. L., and Lee, S. J. K. (1968). Haemodynamic effects of exercise in isolated pulmonary stenosis before and after surgery. British Heart fournal, 30, 60-66.

Kimball, K. G., and McIlroy, M. B. (1966). Pulmonary hypertension in patients with congenital heart disease pre- and post-operative hemodynamics, pulmonary function and criteria for surgical closure of defects. American fournal of Medicine, 41, 883-897.

Kirklin, J. W., DuShane, J. W., Patrick, R. T., Donald, D. E., Hetzel, P. S., Harshbarger, H. G., and Wood, E. H. (1955). Intracardiac surgery with the aid of a mechanical pump oxygenator system (Gibbon type) report of eight cases. Proceedings of the Staff Meetings of the Mayo Clinic, 30, 201-206.

Lee, G., Jr., Matthews, M. B., and Sharpey-Schafer, E. P. (1954). The effect of the Valsalva manoeuvre on the systemic and pulmonary arterial pressure in man. British Heart fournal, 16, 311-316.

Lillehei, C. W., Cohen, M., Warden, H. E., and Varco, R. (1955). Direct vision intracardiac correction of congenital anomalies by controlled cross circulation; results in 32 patients with ventricular septal defects, tetralogy of Fallot and atrio-ventricularis communis defects. Surgery, 38, 11-29.

Lueker, R. D., Vogel, J. H. K., and Blount, S. G. (1969). Cardiovascular abnormalities following surgery for left to right shunts. Circulation, 40, 785-801.

McIlroy, M. B., and Apthorp, G. H. (1958). Pulmonary function in pulmonary hypertension. British Heart fournal, $20,397-402$.

Maron, B. J., Redwood, D. R., Hirshfeld, J. W., Goldstein, R. E., Morrow, A. G., and Epstein, S. E. (1973). Postoperative assessment of patients with ventricular septal defect and pulmonary hypertension. Response to intense upright exercise. Circulation, 48, 864-874.

Ogilvie, C. M., Forster, R. E., Blakemore, W. S., and Morton, J. W. (1957). A standardized breathholding technique for the clinical measurement of the diffusing capacity of the lung for carbon monoxide. Fournal of Clinical Investigation, 36, 1-17.

Spiro, S. G. (1975). Cardiorespiratory adaptation at the start of exercise in normal subjects and patients with chronic obstructive airways bronchitis. Acta Medica Scandinavica, $176,301$.

Tanner, J. M. (1958). Evaluation of physical growth and development. In Modern Trends in Paediatrics, p. 325. Ed. by A. Holzel and J. P. M. Tizard. Butterworth, London.

Turino, G. M., Brandfonbrenner, M., and Fishman, A. P. (1959). The effect of changes in ventilation and pulmonary blood flow on the diffusing capacity of the lung. Fournal of Clinical Investigation, 38, 1186-1201.

Vogel, J. H. K., Grover, R. F., Jamieson, G., and Blount, S. G. (1974). Long term physiologic observations in patients with ventricular septal defect and increased pulmonary vascular resistance. Advances in Cardiology, 11, 198-122.

Wagenvoort, C. A., and Wagenvoort, N. (1974). Pathology of the Eisenmenger syndrome and primary pulmonary hypertension. Advances in Cardiology, 11, 123-130.

Weidman, W. H., and DuShane, J. W. (1974). Course of pulmonary hypertension following surgical closure of ventricular septal defect. Advances in Cardiology, 11, 131-134.

Requests for reprints to Dr. K. A. Hallidie-Smith, Royal Postgraduate Medical School, Hammersmith Hospital, Du Cane Road, London W12 0HS. 